\title{
Analisis karakteristik sosial dan ekonomi usaha pedagang kaki lima di Kecamatan Telanaipura Kota Jambi (studi kasus pedagang nasi goreng)
}

\author{
Alpin Hardiansyah*; Selamet Rahmadi; Parmadi \\ Prodi Ekonomi Pembangunan Fak. Ekonomi dan Binsis Universitas Jambi \\ *E- mail korespodensi: alpininek@gmail.com
}

\begin{abstract}
This study aims to determine and analyze: 1). Social characteristics of fried rice street vendors in Telanaipura District, Jambi City, and 2). Economic characteristics of street vendors of fried rice in Telanaipura District, Jambi City. The data analysis method used is the descriptive quantitative analysis method. The results of the study were obtained: 1). The social conditions of fried rice traders in Telanaipura Sub-district are: the average age is the productive age of 42.78 years, the highest level of education and the most are SMA / SMK, all fried rice traders are male, the marital status is the most married., the average length of effort is 8.39 years, the average number of dependents is 5 people, most fried rice traders have their own homes, most of the original areas of fried rice traders come from Central Java Province, the average length of hours fried rice traders work 9 hours per day and the average fried rice trader has his own business and place of business. 2). The social conditions of fried rice traders in Telanaipura Subdistrict are: venture capital for most fried rice traders is their own, the average amount of initial business capital is $R p .6,233,333$, the average length of day of selling in one month is 28 days, the average price of one serving of fried rice is $R p .13,270.77$.
\end{abstract}

\section{Keywords: Fried rice traders, Social characteristics, Economic characteristics}

\begin{abstract}
Abstrak
Penelitian ini bertujuan untuk mengetahui dan menganalisis : 1). Karakteristik sosial pedagang kaki lima nasi goreng di Kecamatan Telanaipura Kota Jambi dan 2). Karakteristik ekonomi pedagang kaki lima nasi goreng di Kecamatan Telanaipura Kota Jambi. Metode analisis data yang digunakan adalah menggunakan metode analisis deskriptif kunatitatif. Hasil penelitian diperoleh : 1). Kondisi sosial pedagang nasi goreng di Kecamatan Telanaipura adalah : usia rata-rata adalah usia produktif yaitu 42,78 tahun, tingkat pendidikan tertinggi dan paling banyak adalah SMA/SMK, semua pedagang nasi goreng berjenis kelamin laki-laki, status perkawinan paling banyak telah kawin, rata-rata lama berusaha 8,39 tahun, rata-rata jumlah tanggungan keluarga 5 orang, pedagang nasi goreng paling banyak telah memiliki sendiri rumah tempat tinggal, daerah asal pedagang nasi goreng palin banyak berasal dari Provinsi Jawa Tengah, rata-rata lama jam kerja pedagang nasi goreng 9 jam perhari dan rata-rata pedagang nasi goreng memiliki usaha dan tempat usaha sendiri. 2). Kondisi sosial pedagang nasi goreng di Kecamatan Telanaipura adalah: modal usaha pedagang nasi goreng paling banyak adalah milik sendiri, rata-rata besarnya modal awal usaha adalah $\mathrm{Rp}$. 6.233.333, rata-rata lama hari berjualan dalam satu bulan adalah 28 hari, rata-rata harga satu porsi nasi goreng adalah Rp. 13.270,77.
\end{abstract}

Kata kunci : Pedagang nasi goreng, Karakteristik sosial; Karakteristik ekonomi 


\section{PENDAHULUAN}

Pengembangan dan perlindungan usaha kecil dan sektor informal harus bertumpu pada mekanisme pasar yang sehat dan adil. Pemerintah daerah perlu melakukan langkah strategis yang harus ditempuh demi perlindungan usaha kecil dan sektor informal. Kebanyakan usaha sektor informal dibentuk dari ekonomi kerakyatan, keberadaannya di era otonomi daerah merupakan potensi yang harus digali dan dikembangkan karena dapat menyerap tenaga kerja dalam jumlah yang cukup tinggi dan dapat meningkatkan kesejahteraan masyarakat sebagaimana tujuan dari pembangunan daerah.

Banyak bidang informal yang berpotensi untuk diangkat dan digali menjadi salah satu bidang usaha yang menghasilkan keuntungan dan income keluarga sekaligus dapat menyerap tenga kerja. Usaha berdagang merupakan salah satu alternatif lapangan kerja informal, yang ternyata banyak menyerap tenaga kerja, seperti pedagang informal di Telanaipura Kota Jambi, Pendapatan pedagang informal dapat menjadi tumpuan pendapatan keluarga. Pada umumnya para pedagang mempunyai tujuan utama mendapatkan laba tertentu ( mungkin maksimal ) dan mempertahankan atau semakin berusaha meningkatkannya.

Untuk itu usaha sektor informal dalam perkembangannya yang semakin luas dan nyata perlu dibina dan dilindungi agar tumbuh menjadi unsur kekuatan ekonomi. Dalam usaha perkembangan usaha sektor informal sangat diperlukan peranan pemerintah. Dalam hal ini pemerintah harus selalu berupaya untuk mendorong dan menciptakan iklim usaha yang kondusif agar usaha kecil tersebut dapat terus tumbuh dan berkembang dengan baik. Dengan demikian, usaha kecil akan menjadi kekuatan ekonomi yang tangguh dan mandiri serta dapat memperkuat struktur perekonomian nasional sehingga usaha kecil benarbenar menjadi tulang punggung perekonomian nasional. (Prawirokusumo, 2001).

Kemampuan sektor informal dalam menampung tenaga kerja didukung oleh faktor-faktor yang ada. Faktor utama adalah sifat dari sektor ini yang tidak memerlukan persyaratan dan tingkat keterampilan, sektor modal kerja, pendidikan ataupun saranayang dipergunakan semuanya serba sederhana dan mudah dijangkau oleh semua anggota masyarakat atau mereka yang belum memiliki pekerjaan dapat terlibat didalamnya. Salah satu sektor yang kini menjadi perhatian para pencari lapangan pekerjaan adalah sektor tenaga kerja yang sifatnya informal. Sektor informal ini beroperasi pada tempat-tempat tertentu terutama di setiap pusat keramaian.Breman dalam Darman (2015) menyatakan bahwa sektor informal meliputi masa pekerja kaum miskin yang tingkat produktifitasnya jauh lebih rendahdari pada pekerja di sektor modern di kota yang tertutup bagi kaum miskin..

Berdasarkan data dari penanaman koordinasi modal (BKPM, 2018) banyak para pekerja yang sebelumnya bekerja sektor formal, lari ke sektor informal. Hal ini membuat sektor informal menguat tinggi. Berdasarkan identifikasi tersebut, maka pada Januari - Juni 2017 penduduk Indonesia yang bekerja di sektor formal mencapai 539.457 orang dan turun pada bulan januari-juni 2018 hanya sebanyak 491.082 orang. Sedangkan jumlah pekerja sektor informal di Kota Jambi menurut Dinas Tenaga Kerja, Koperasi dan UKM Kota Jambi (2018) sebanyak 21.476 Orang.

Berdasarkan data yang dihimpun dari Dinas Tenaga Kerja Koperasi dan UKM Provinsi Jambi (2019) ada sebanyak 514 PKL yang terdaftar diseluruh kelurahan yang ada di Kecamatan Telanaipura. Berikut ini dapat dilihat jenis dan jumlah PKL yang terdaftar di Kecamatan Telanaipura Kota Jambi. Berdasarkan Tabel 1. dapat dilihat bahwa nasi goreng merupakan salah satu jenis dagangan terbanyak di Kecamatan 
Telanaipura yaitu sebanyak 39 unit. Banyaknya jumlah pedagang nasi goreng dikarenakanbanyaknya minat masyarakat untuk membeli nasi goreng terutama di malam hari.

Tabel 1. Pedagang kaki lima (PKL) di Kecamatan Telanaipura Kota Jambi tahun 2019

\begin{tabular}{clc}
\hline No. & Jenis Dagangan & Jumlah \\
\hline 1 & Nasi Goreng & 39 \\
2 & Nasi Uduk Pecel Lele & 26 \\
3 & Sop dan Soto & 24 \\
4 & Gorengan & 26 \\
5 & Sate Padang & 14 \\
6 & Martabak & 12 \\
7 & Tekwan, Bakso & 33 \\
8 & Hot Pangsit, Qitela, Bakso Bakar & 16 \\
9 & Capucino Cincau, Jasuke, Es Doger, Es Tebu & 25 \\
10 & Kue & 6 \\
11 & Warung Manisan & 50 \\
12 & Daging, Ikan, dan Ayam & 49 \\
13 & Bumbu dan Sayuran & 39 \\
14 & Gado-gado, nasi gemuk, lontong & 46 \\
15 & Warung Kopi, Bandrek & 29 \\
16 & Tempel Ban, Cucian Motor & 19 \\
17 & Counter HP & 31 \\
18 & Buah-Buahan & 21 \\
19 & Sol Sepatu & 9 \\
\hline & & $\mathbf{5 1 4}$
\end{tabular}

Sumber: BPS, Kecamatan Telanaipura dalam angka, 2019(diolah)

Selanjutnya, pedagang berjualan nasi goreng tentunya karena ingin mendapatkan pendapatan yang digunakan untuk memenuhi kebutuhan hidup keluarga. Pendapatan masing-masing pedagang tentunya berbeda-beda nilainya, hal ini dikarenakan perbedaan karakteristik sosial dan ekonomi pedagang nasi goreng yang juga berbeda-beda. Karaktertik sosial antara lain umur, jenis kelamin, status menikah dan jumlah tanggungan. Selanjutnya karakteristik ekonomi antara lain lama usaha, jam kerja, lokasi usaha, harga nasi goreng, modal tetap, modal operasional, produksi, omset dan pendapatan bersih. Berdasarkan uraian diatas, maka penulis tertarik untuk melakukan penelitian lebih lanjut dalam bentuk skripsi yangberjudul "Analisis karakteristik sosial dan ekonomi usaha pedagang kaki lima di Kecamatan Telanaipura Kota Jambi (studi kasus pedagang nasi goreng).

\section{METODE}

Adapun jenis penelitian yang digunakan dalam penelitian ini adalah metode survei. Metode survei adalah penelitian yang mengambil sampel dari populasi dengan menggunakan kusioner sebagai alat pengumpul data dimana peneliti langsung ke lokasi penelitian untuk mengumpulkan data serta fakta dari gejala-gejala yang ada untuk mencari keterangan keterangan secara faktual (Arikunto, 2010).

Teknik pengumpulan data merupakan cara yang ditempuh untuk memperoleh data yang diperlukan dalam suatu penelitian dengan menggunakan suatu alat tertentu. Teknik pengumpulan data yang digunakan dalam penelitian ini adalah sebagai berikut : 
Data primer menurut Wahyuni (2011) adalah data yang didapat langsung dari sumbernya dan dikumpulkan oleh peneliti sendiri, yaitu pedagang nasi goreng di Kecamatan Telanaipura Kota Jambi. Adapun metode yang dapat dilakukan dalam mengumpulkan data primer adalah dengan cara :

\section{Wawancara}

Wawancara adalah pengumpulan data yang dilakukan dengan studi pendahuluan untuk menemukan permasalahan yang harus diteliti serta untuk mengetahui hal-hal dari responden yang lebih mendalam (Sugiyono, 2012). Wawancara yang dilakukan adalah wawancara terstruktur, dimana peneliti sudah menyiapkan kusioner sebelumnya. Dalam hal ini wawancara dilakukan dengan PKL nasi goreng di Kecamatan Telanaipura Kota Jambi. Wawancara dilakukan untuk memperoleh informasi secara langsung juga untuk mempermudah dalam memperoleh data untuk pengisian kuesioner.

\section{Kuesioner}

Kuesioner merupakan teknik pengumpulan data yang dilakukan dengan cara memberi seperangkat pertanyaan atau pernyataan tertulis kepada responden untuk dijawabnya (Sugiyono, 2012). Jenis angket yang digunakan adalah angket terbuka. Angket terbuka yaitu angket yang disajikan dalam bentuk sedemikian rupa sehingga responden dapat memberikan isian sesuai dengan kehendak dan keadaannya. Angket terbuka dipergunakan apabila peneliti belum dapat memperkirakan atau menduga kemungkinan alternatif jawaban yang ada pada responden. Dimana peneliti memberikan sejumlah pertanyaan uraian dan responden diberikan kebebasan untuk menjawab sesuai keadaan sebenarnya.

Wahyuni (2011), populasi merupakan sebagai keseluruhan atau totalitas dari semua unsur-unsur dari suatu objek yang diamati dan diteliti. Sementara itu populasi juga merupakan sebagai totalitas dari semua objek atau individu tertentu, jelas dan lengkap yang akan diteliti. Dalam penelitian ini populasinya adalah pedagang kaki lima nasi goreng yang berjualan di Kecamatan Telanaipura Kota Jambi. Populasi tersebut berjumlah 39 pedagang nasi goreng. Populasi pedagang nasi goreng yang ada di Kecamatan Telanaipura semuanya dijadikan sebagai sampel. Dasar semua populasi dijadikan sebagai sampel, karena dalam penelitian ini menggunakan metode area (Area Sampling). Metode Area adalah metode pengambilan sampel berdasarkan pada area atau lokasi tertentu. (Wahyuni, 2011).

Untuk mencapai tujuan penelitian pertama dan kedua yaitu karakteristik sosial dan ekonomi pedagang kaki lima nasi goreng di Kecamatan Telanaipura, maka analisis data yang digunakan adalah analisis deskriptf kualitatif. Sujarweni (2015) mengartikan analisis deskriptif adalah pengolahan data yang bertujuan untuk mendeskripsikan atau memberi gambaran terhadap objek yang diteliti melalui data sampel atau populasi.

\section{HASIL DAN PEMBAHASAN}

\section{Karakteristik sosial pedagang nasi goreng berdasarkan usia}

Penduduk merupakan unsur penting dalam usaha meningkatkan produksi dan mengembangkan kegiatan ekonomi. Penduduk yang besar berperan dalam menyediakan tenaga kerja produktif yang diperlukan untuk menciptakan kegiatan ekonomi. Kegiatan produktif penduduk dalam menghasilkan barang dan jasa ditentukan oleh faktor usia selain faktor yang lain. Usia penduduk termasuk dalam usia produktif, bila termasuk dalam usia kerja yaitu 15 - 64. (Mulyadi, 2005). Berdasarkan pengertian penduduk usia 
produktif diatas, maka pedagang nasi goreng yang berada di Kecamatan Telanaipura Kota Jambi yang menjadi responden dalam penelitian ini semuanya merupakan tenaga kerja yang berusia produktif dengan rata-rata usianya adalah 42,78 tahun atau 42 tahun 8 bulan. Jumlah pedagang yang memiliki usia terletak antara 43 - 47 tahun merupakan jumlah terbesar dari pedagang nasi goreng dengan jumlah 13 pedagang atau 33,33\%. Jumlah pedagang kelontong terkecil terletak pada usia antara 28 - 32 tahun, usia antara $48-52$ tahun dan usia antara 53 - 57 tahun yaitu masing-masing berjumlah 3 pedagang atau $10,26 \%$. Usia pedagang kelontong yang terletak antara 33 - 37 tahun berjumlah 6 pedagang atau $15,38 \%$, sementara usian pedagang nasi goreng yang terletak antara usia 38 - 42 tahun berjumlah 8 pedagang atau 20,51\% dari total keseluruhan pedagang nasi goreng di Kecamatan Telanaipura Kota Jambi.

Tabel. 2. Usia pedagang nasi goreng (tahun)

\begin{tabular}{lcc}
\hline Usia & Jumlah & \% \\
\hline $28-32$ & 4 & 10,26 \\
$33-37$ & 6 & 15,38 \\
$38-42$ & 8 & 20,51 \\
$43-47$ & 13 & 33,33 \\
$48-52$ & 4 & 10,26 \\
$53-57$ & 4 & 10,26 \\
\hline Total & $\mathbf{3 9}$ & $\mathbf{1 0 0 , 0 0}$ \\
\hline Usia termuda : 28 tahun & & \\
Usia tertua : 55 tahun & & \\
Rata-rata usia: 42,78 tahun & & \\
\hline
\end{tabular}

Sumber: Data diolah, 2020

\section{Tingkat pendidikan dan jenis kelamin}

Pendidikan adalah merupakan ukuran kemajuan suatu daerah dan kualitas sumberdaya manusia (SDM) yang dimiliki. Semakin tinggi tingkat pendidikan suatu daerah, maka mencerminkan kualitas SDM yang dimiliki semakin tinggi atau baik dan kondisi sebaliknya, semakin rendah tingkat pendidikan suatu daerah, maka mencerminkan kualitas SDM yang dimiliki semakin rendah.

Tabel. 3. Pendidikan pedagang nasi goreng

\begin{tabular}{ccc}
\hline Pendidikan Formal & Jumlah & \% \\
\hline SD & 6 & 15,38 \\
SMP & 7 & 17,95 \\
SMA/SMK & 26 & 66,67 \\
\hline Total & $\mathbf{3 9}$ & $\mathbf{1 0 0 , 0 0}$ \\
\hline
\end{tabular}

Sumber: Data diolah, 2020

Jika dilihat dari tingkat pendidikan yang diselesaikan, maka tingkat pendidikan pedagang nasi goreng dari 39 pedagang nasi goreng di Kecamatan Telanaipura Kota Jambi tertinggi adalah sekolah menengah atas sederajat (SMA/SMK). Tingkat pendidikan terbesar pedagang nasi goreng dari 39 pedagang yaitu memiliki tingkat pendidikan Sekolah Menengah Atas (SMA/SMK) yaitu 26 pedagang nasi goreng atau 66,67\%. Pedagang nasi goreng yang memiliki tingkat pendidikan SD berjumlah 6 pedagang nasi goreng atau $15,38 \%$. Selanjutnya pedagang nasi goreng yang memiliki tingkat 
pendidikan SMP berjumlah 7 pedagang nasi goreng atau 17,95 \%. Pedagang nasi goreng yang berjumlah 39 orang yang berada di Kecamatan Telanaipura semua memiliki jenis kelamin laki-laki.

\section{Status perkawinan}

Status perkawinan sangat menentukan seseorang untuk memiliki tanggung jawab yang lebih besar atau tidak. Seseorang termasuk pedagang nasi goreng di Kecamatan Telanaipura yang memiliki istri atau sudah beristri, biasanya akan memiliki tanggung jawab yang besar dalam memenuhi kebutuhan hidup sehari- hari di banding pedagang nasi goreng yang belum menikah atau belum memiliki istri.

Tabel. 4. Status perkawinan pedagang nasi goreng

\begin{tabular}{|c|c|c|}
\hline Pendidikan Formal & Jumlah & $\%$ \\
\hline Belum Kawin & 6 & 15,38 \\
\hline Kawin & 33 & 85,62 \\
\hline Total & 39 & 100,00 \\
\hline
\end{tabular}

Sumber: Data diolah, 2020

Jika dilihat dari status perkawinan dari pedagang nasi goreng yang berjualan di Kecamatan Telanaipura, maka status perkawinan pedagang nasi goreng dari 39 pedagang nasi goreng di Kecamatan Telanaipura Kota Jambi terbesar adalah memiliki status kawin yaitu 33 pedagang nasi goreng atau $85,62 \%$. Pedagang nasi goreng yang memiliki status belum kawin berjumlah 6 pedagang nasi goreng atau 15,38 \% .

\section{Lama berusaha}

Lama berusaha dari suatu aktivitas turut mempengaruhi perkembangan usaha yang dilakukan, karena dengan pengalaman berusaha yang semakin lama akan mendorong perkembangan usaha terlebih dilihat dari pengalaman, penguasaan pasar, akses pasar dan lainnya. Melihat lamanya waktu berusaha dari 39 pedagang nasi goreng di Kecamatan Telanaipura Kota Jambi, ternyata memiliki rata-rata lama berusaha 8 tahun 4 bulan. Pedagang naso goreng yang memiliki tahun lama usaha paling rendah 4 tahun sementara yang memiliki lama usaha paling lama adalah 13 tahun. Persentase lama berusaha terbesar terletak antara $8-9$ tahun yang berjumlah 12 pedagang atau 30,77\% dari keseluruhan 39 jumlah pedagang nasi goreng. Sementara persentase lama berusaha terkecil/terendah terletak $>12$ tahun yaitu berjumlah 4 pedagang atau 10,26\% .

Tabel. 5. Lama berusaha pedagang nasi goreng (dalam tahun)

\begin{tabular}{ccc}
\hline Lama berusaha & Jumlah & \% \\
\hline $4-5$ & 6 & 15,38 \\
$6-7$ & 8 & 20,51 \\
$8-9$ & 12 & 30,77 \\
$10-11$ & 9 & 23,08 \\
$>12$ & 4 & 10,26 \\
TOTAL & $\mathbf{3 9}$ & $\mathbf{1 0 0 , 0 0}$ \\
\hline
\end{tabular}

Lama usaha terendah : 4 tahun

Lama usaha terlama : 13 tahun

Rata-Rata lama usaha : 8,39 tahun

Sumber: Data diolah, 2020 
Sementara pedagang nasi goreng yang lama berusaha terletak antara $4-5$ tahun berjumlah 6 pedagang atau $15,38 \%$. Selanjutnya pedagang yang memiliki pengalaman berusaha terletak antara $6-7$ tahun berjumlah 8 pedagang atau 20,51\% serta lama berusaha terletak antara $10-11$ tahun berjumlah 9 pedagang atau 23,08 \% .

\section{Jumlah tanggungan keluarga}

Hasil kuesioner juga memperlihatkan selain usia, pendidikan dan lama berusaha, persentase terbesar responden berdasarkan jumlah tanggungan keluarga atau orang yang menetap dan tinggal dalam suatu keluarga, maka jumlah tanggungan keluarga pedagang nasi goreng paling sedikut adalah 2 orang dan paling banyak adalah 8 orang. Sementara dari 39 pedagang nasi goreng di Kecamatan Telanaipura, maka rata-rata memiliki jumlah tanggungan keluarga sebesar 4,74 orang atau 5 orang.

Tabel. 6. Jumlah tanggungan keluarga pedagang nasi goreng (orang)

\begin{tabular}{ccc}
\hline Jumlah tanggungan & Jumlah & \% \\
\hline$<4$ & 6 & 15,38 \\
$4-5$ & 24 & 61,53 \\
$6-7$ & 7 & 17,95 \\
$>7$ & 2 & 5,14 \\
Total & $\mathbf{3 9}$ & $\mathbf{1 0 0 , 0 0}$ \\
\hline
\end{tabular}

Jumlah tanggungan keluarga terendah : 2 orang

Jumlah tanggungan keluarga terbesar : 8 orang

Rata-rata jumlah tanggungan keluarga : 4,74 atau 5 orang

Sumber: Data diolah, 2020

Persentase terbesar jumlah anggota keluarga pedagang nasi goreng, terletak antara $4-5$ orang yang berjumlah 24 pedagang nasi goreng atau 61,53\%. Pedagang nasi goreng di Kecamatan Telanaipura yang jumlah anggota keluarganya $<4$ orang berjumlah 6 pedagang nasi goreng atau 15,38\%. Sementara jumlah tanggungan keluarga berjumlah 6 pedagang nasi goreng memiliki jumlah tanggungan keluarga antara $6-7$ orang atau 17,95 $\%$ dan yang memiliki jumlah tanggungan keluarga $>7$ orang berjumlah 2 pedagang nasi goreng atau $5,14 \%$.

\section{Kepemilikan rumah}

Status sosial seseorang banyak faktor untuk dapat melihatnya selain yang telah disebutkan diatas. Jika dilihat status sosial pedagang nasi goreng di Kecamatan Telanaipura dilihat dari kepemilikan rumah yang dijadikan tempat tinggal, maka dari 39 orang pedagang nasi goreng dari hasil penelitian hanya dapat diklasifikasikan atas dua (2) kelompok yaitu rumah milik sendiri dan rumah menyewa. Berdasarkan hasil penelitian, pedagang nasi goreng yang memiliki rumah sendiri berjumlah 26 orang pedagang nasi goreng atau $66,67 \%$ sedangkan sisanya berjumlah 13 orang pedagang nasi goreng atau 33,33\% rumah tempat tinggalnnya adalah menyewa. Kondisi ini, menghambarkan, status sosial pedagang nasi goreng di Kecamatan Telanaipura adalah cenderung baik

Tabel. 7. Status kepemilikan rumah tempat tinggal pedagang nasi goreng

\begin{tabular}{ccc}
\hline Status Rumah & Jumlah & \% \\
\hline Milik Sendiri & 26 & 66,67 \\
Sewa & 13 & 33,33 \\
\hline Total & $\mathbf{3 9}$ & $\mathbf{1 0 0 , 0 0}$
\end{tabular}

Sumber: Data diolah, 2020 


\section{Asal daerah dan pekerjaan lain}

Daerah asal pedagang sangat menentukan keberhasilan di dalam berusaha. Keberhasilan berusaha juga tergantung dari kebiasaan yang dilakukan masyarakat suatu daerah yang di bawak di daerah lain, dimana tempat mereka berusaha atau mencari nafkah. Jika dilihat dari pedagang nasi goreng yang ada di Kecamatan Telanaipura diperoleh gambaran, bahwa daerah asal pedagang nasi goreng cukup terebar daerah asalnya. Daerah asal pedagang nasi goreng di Kecamatan Telanaipura berasal dari : Jawa Tengah, Jawa Timur, Jawa Barat, Jakarta, Yogyakarta, Aceh, Sumatera Barat, Jambi, Sumatera Selatan, Riau dan Lampung.

\section{Lama jam bekerja}

Pedagang nasi goreng di Kecamatan Telanaipura yang berjumlah 39 pedagang nasi goreng, rata-rata memiliki lama jam bekerja adalah 8,74 jam perhari dan jam kerja terlama adalah 11 jam perhari sedangkan yang terendah adalah 7 jam perhari. Lama berkerja, pedagang nasi goreng di Kecamatan Telanaipura di mulai dari jam 15.00 Wib sampai jam $24.00 \mathrm{Wib}$, walaupun ada pedagang nasi goreng yang mulai berusaha bukan dari jam 15.00 Wib, tetapi di bawah jam 15.00 Wib.

Tabel. 8. Lama jam bekerja pedagang nasi goreng (jam/hari)

\begin{tabular}{ccc}
\hline Lama Jam Bekerja & Jumlah & \% \\
\hline $7-8$ & 16 & 41,02 \\
$9-10$ & 21 & 53,85 \\
$>10$ & 2 & 5,13 \\
\hline Total & $\mathbf{3 9}$ & $\mathbf{1 0 0 , 0 0}$ \\
\hline Lama Jam Bekerja terendah : 7 jam & & \\
Lama Jam Bekerja terlama : 11 jam & \\
Rata-rata Lama Jam Bekerja: 8,74 atau 9 jam & \\
\hline
\end{tabular}

Sumber: Data diolah, 2020

Pedagang nasi goreng di Kecamatan Telanaipura didominasi pedagang yang bekerja terletak antara $9-10$ jam perhari yang berjumlah 21 pedagang nasi goreng atau $41,02 \%$. Pedagang nasi goreng di Kecamatan Telanaipura yang bekerja terletak antara 7 -8 jam perhari adalah berjumlah 16 pedagang nasi goreng atau $41,02 \%$. Sementara yang memiliki jam lama bekerja > 10 jam perhari berjumlah 2 pedagang nasi goreng atau 5,13 $\%$.

\section{Karakteristik ekonomi pedagang nasi goreng berdasarkan asal modal usaha}

Pedagang nasi goreng yang berada di Kecamatan Telanaipura Kota Jambi yang berjumlah 39 pedagang, ternyata $64,11 \%$ atau 25 pedagang nasi gorang, modalnya merupakan memiliki sendiri. Modal usaha yang berasal dari modal keluarga berjumlah 6 pedagang nasi goreng atau $15,38 \%$ sedangkan modal usaha yang dimiliki bersama orang lain berjumlah 8 pedagang nasi goreng atau 20,51\%. Kondisi besarnya jumlah pedagang yang modal usahanya merupakan milik sendiri yaitu lebih dari 64,11\% merupakan kondisi yang sangat menguntungkan bagi pedagang nasi goreng, karena pedagang nasi goreng dapat mengembangkan usaha atau memperkuat modal usaha di masa datang tanpa bagi hasil. 
Tabel. 9. Asal modal usaha pedagang nasi goreng

\begin{tabular}{clcc}
\hline No & Asal Modal Usaha & Jumlah & \% \\
\hline 1 & Milik Sendiri & 25 & 64,11 \\
2 & Milik Keluarga & 6 & 15,38 \\
3 & Milik Bersama & 8 & 20,51 \\
\hline \multicolumn{2}{c}{ TOTAL } & $\mathbf{3 9}$ & $\mathbf{1 0 0 , 0 0}$ \\
\hline
\end{tabular}

Sumber: Data diolah, 2020

\section{Besar modal awal usaha}

Modal awal usaha, merupakan faktor penentu keberhasilan dalam melakukan usaha selain faktor usia, pendidikan, lama berusaha dan lain sebagainya. Besarnya modal awal usaha sangat menentukan besar kecilnya usaha yang dilakukan. Modal yang besar, maka akan membuat seseorang pelaku usaha akan mampu mendirikan usaha dalam kapasitas yang besar dan sebaliknya, jika modal awal usaha yang terbatas atau kecil maka kapasitas usaha yang dapat dilakukan juga dalam ukuran yang terbatas atau kecil.

Berdasarkan hasil temuan dilapangan memperlihatkan, bahwa rata-rata dari 39 pedagang nasi goreng di Kecamatan Telanaipura Kota Jambi memiliki besar modal awal dalam melakukan kegiatan usahanya adalah sebesar Rp. 6.233.333. Modal awal usaha pedagang nasi goreng terbesar yaitu Rp. 10.000.000 dan yang terkecil yaitu dengan modal awal usaha sebesar Rp. 2.300.000.

Kondisi modal awal usaha pedagang nasi goreng tersebut bukanlah kondisi yang bisa mengembangkan usahanya, justru dengan modal awal usaha yang kecil dapat mengembangkan usahanya di banding modal awal usaha yang besar. Jika dilihat secara rinci, maka pedagang nasi goreng yang berjumlah 39 pedagang yang dijadikan responden dalam penelitian ini, di dominasi dengan modal awal usaha terletak antara Rp. 4.866.000 - Rp. 6.148.000 yang berjumlah 12 pedagang nasi goreng atau 30,78 \%. Sementara kondisi modal awal pedagang nasi goreng dengan modal awal usaha di atas Rp. 7.432.000 - Rp. 8.714.000 hanya berjumlah 3 pedagang atau 7,69 \% .

Tabel. 10. Modal awal usaha pedagang nasi goreng

\begin{tabular}{ccc}
\hline Modal Awal Usaha (Rp) & Jumlah & \% \\
\hline $2.300 .000-3.582 .000$ & 4 & 10,26 \\
$3.583 .000-4.865 .000$ & 6 & 15,38 \\
$4.866 .000-6.148 .000$ & 12 & 30,78 \\
$6.149 .000-7.431 .000$ & 6 & 15,38 \\
$7.432 .000-8.714 .000$ & 3 & 7,69 \\
$>8.714 .000$ & 8 & 20,51 \\
\hline Total & $\mathbf{3 9}$ & $\mathbf{1 0 0 , 0 0}$ \\
\hline
\end{tabular}

Modal Awal Usaha Terendah : Rp. 2.300.000

Modal Awal Usaha Tertinggi : Rp. 10.000.000

Rata-Rata Modal Awal Usaha : Rp. 6.233.333

Sumber: Data diolah, 2020

Jumlah pedagang nasi goreng yang memulai usaha dengan modal awal terletak antara Rp. 2.300 .000 - Rp. 3.582 .000 berjumlah 4 pedagang atau 10,26 \% dari keseluruhan pedagang. Jumlah modal awal usaha pedagang nasi goreng yang besarannya terletak antara Rp. 3.583.000 - Rp. 4.865 .000 dan antara Rp. 6.149.000 - Rp. 7.431.000 masing-masing berjumlah 6 pedagang atau 15,38 \%. Pedagang nasi goreng yang memiliki modal awal usaha $>8.714 .000$ berjumlah 8 pedagang nasi goreng atau 20,51 $\%$. 


\section{Lama hari berjualan}

Pedagang nasi goreng di Kecamatan Telanaipura, besarnya pendapatan yang diterima ditentukan oleh lamanya kegiatan usaha yang dilakukan selama satu bulan. Semakin lama hari berjualan dalam satu bulan yang dilakukan oleh pedagang nasi goreng di harapkan akan mampu menentukan besarnya pendapatan yang diterima oleh pedagang tersebut. Semakin lama pedagang nasi goreng menggunakan hari dalam satu bulan untuk berjualan, maka diharapkan akan memberikan pendapatan yang semakin besar dan sebaliknya, yaitu lamanya hari berjualan yang semakin pendek atau tidak lama dalam satu bulan, maka akan memberikan pendapatan yang semakin kecil atau rendah. Berdasarkan hasil penelitian, diperoleh lama hari dalam satu bulan yang digunakan pedagang nasi goreng di Kecamatan Telanaipura untuk berjualan terlihat pada tabel di bawah ini.

Tabel. 11. Lama hari berjualan pedagang nasi goreng (hari/bulan)

\begin{tabular}{ccc}
\hline Lama Hari & Jumlah & \% \\
\hline$<26$ & 6 & 15,39 \\
$\geq 26$ & 33 & 84,61 \\
Total & $\mathbf{3 9}$ & $\mathbf{1 0 0 , 0 0}$ \\
\hline
\end{tabular}

Lama hari berjualan terendah: 25 hari dalam satu bulan

Lama hari berjualan tertinggi: 30 hari dalam satu bulan

Rata-rata lama hari berjulan: 28 hari dalam satu bulan

Sumber: Data diolah, 2020

Hari yang digunakan pedagang nasi goreng di Kecamatan Telanaipura paling rendah untuk berjualan adalah 25 hari dalam satu bulan dan yang tertinggi adalah 30 hari. Sementara hari yang digunakan untuk berdagang oleh pedagang nasi goreng selama satu bulan rata-rata adalah 28 hari. Pedagang nasi goreng yang berjualan dalam satu bulan dengan menggunakan lamanya hari berjualan $<26$ hari berjumlah 6 pedagang nasi goreng atau $15,39 \%$ dan yang menggunakan lamanya hari berjualan $\geq 26$ hari berjumlah 33 pedagang nasi goreng atau $84,61 \%$.

\section{Harga dan porsi nasi goreng terjual}

Pedagang nasi goreng sebagai bagian pedagang kaki lima, uasahanya akan bertahan atau berkembang tergantung dari jumlah produk yang dijual yaitu jumlah porsi nasi goreng di jual perharinya serta harga jual yang ditetapkan untuk satu porsi nasi goreng. Harga jual sangat menentukan persaingan dengan sesama pedagang nasi goreng lain dalam menarik pembeli atau pelanggan. Pedagang nasi goreng di Kecamatan Telanaipura menjual nasi goreng dengan harga per porsinya adalah antara Rp. 12.000 dan Rp. 15.000. Rata-rata nasi goreng yang dijual oleh pedagang nasi goreng yang berjumlah 39 pedagang nasi goreng di Kecamatan Telanaipura rata-rata satu porsinya adalah Rp. 13.270,77.

Tabel. 12. Jumlah porsi nasi goreng yang terjual

\begin{tabular}{cccccc}
\hline $\begin{array}{c}\text { Jumlah porsi nasi } \\
\text { goreng (hari) }\end{array}$ & Jumlah & $\boldsymbol{\%}$ & $\begin{array}{c}\text { Jumlah Porsi Nasi } \\
\text { Goreng(bulan) }\end{array}$ & Jumlah & $\%$ \\
\hline$<14$ & 17 & 43,59 & $<405$ & 21 & 53,84 \\
$14-18$ & 18 & 46,15 & $405-470$ & 9 & 23,08 \\
$>18$ & 4 & 10,26 & $>470$ & 9 & 23,08 \\
\hline Total & $\mathbf{3 9}$ & $\mathbf{1 0 0 , 0 0}$ & Total & $\mathbf{3 9}$ & $\mathbf{1 0 0 , 0 0}$ \\
\hline Porsi Terjual Terendah $: 7$ porsi & & Porsi Terjual Terendah & $: 210$ porsi \\
Porsi Terjual Tertinggi : 20 porsi & Porsi Terjual Tertinggi & $:$ 600 porsi \\
Rata-Rata Porsi Terjual : 13,31 porsi & Rata-Rata Porsi Terjual & $: 386,46$ porsi \\
\hline
\end{tabular}

Sumber: Data diolah, 2020 
Jumlah porsi nasi goreng yang berhasil dijual oleh pedagang nasi goreng di Kecamatan Telanaipura perbulan rata-rata adalah sebanyak 386,46 porsi atau 387 porsi. Jumlah porsi nasi goreng terjual paling rendah adalah 210 porsi perbulan dan tertinggi atau terbanyak adalah 600 porsi perbulan. Porsi nasi goreng yang terjual per bulan oleh pedagang nasi goreng terbanyak terletak antara $405-470$ porsi perbulan yaitu berjumlah 9 pedagang nasi goreng atau $23,08 \%$ dan porsi nasi goreng terjual $>470$ porsi perbulan ada 9 pedagang nasi goreng atau $23,08 \%$. Sementara yang berhasil menjual nasi goreng perbulan $<405$ porsi berjumlah 21 pedagang nasi goreng atau $21,84 \%$ dan merupakan persentase paling besar dari 39 pedagang nasi goreng.

\section{Biaya usaha}

Biaya usaha yang dikeluarkan pedagang nasi goreng di Kecamatan Telanaipura rata-rata perhari adalah sebesar Rp. 66.538. Biaya usaha perhari terbesar dari pedagang nasi goreng yang dikeluarkan adalah Rp. 100.000 dan yang paling kecil adalah sebesar Rp. 35.000. Adapun biaya perhari pedagang nasi goreng yang besarannya $<\mathrm{Rp} .40 .000$ berjumlah 10 pedagang nasi goreng atau 15,38 \%. Pedagang nasi goreng yang biaya usahanya dikeluarkan terletak antara Rp. 41.000 - Rp. 60.000 berjumlah 11 orang atau $28,20 \%$. Pedagang nasi goreng yang biaya usahanya dikeluarkan terletak antara $\mathrm{Rp}$. 61.000 - Rp. 80.000 masing-masing berjumlah 13 pedagang nasi goreng atau 33,33\% . Biaya usaha yang terletak antara Rp. > 80.000 di Kecamatan Telanaipura, berjumlah 9 pedagang nasi goreng atau $23,08 \%$.

Tabel. 13. Biaya usaha yang dikeluarkan pedagang nasi goreng(Rp/hari)

\begin{tabular}{ccc}
\hline Biaya Usaha & Jumlah & \% \\
\hline$<40.000$ & 6 & 15,38 \\
$41.000-60.000$ & 11 & 28,20 \\
$61.000-80.000$ & 13 & 33,33 \\
$>80.000$ & 9 & 23,08 \\
\hline Total & $\mathbf{3 9}$ & $\mathbf{1 0 0 , 0 0}$ \\
\hline
\end{tabular}

Biaya usaha terendah : Rp. 35.000

Biaya usaha tertinggi : Rp. 100.000

Rata-rata biaya usaha : Rp. 66.538

Sumber: Data diolah, 2020

Biaya usaha yang dikeluarkan pedagang nasi goreng di Kecamatan Telanaipura rata-rata perbulan adalah sebesar Rp. 1.857.821. Biaya usaha perbulan terbesar dari pedagang nasi goreng yang dikeluarkan adalah Rp. 2.700 .000 dan yang paling kecil adalah sebesar Rp. 1.000 .000

Tabel. 14. Biaya usaha yang dikeluarkan pedagang nasi goreng(rp/bulan)

\begin{tabular}{ccc}
\hline Biaya Usaha & Jumlah & \% \\
\hline$<1.000 .000$ & 1 & 2,56 \\
$1.001 .000-1.500 .000$ & 16 & 41,02 \\
$1.501 .000-2.000 .000$ & 4 & 10,26 \\
$2.001 .000-2.500 .000$ & 14 & 35,90 \\
$>2.500 .000$ & 4 & 10,26 \\
\hline Total & $\mathbf{3 9}$ & $\mathbf{1 0 0 , 0 0}$
\end{tabular}

Biaya usaha terendah: Rp. 1.000 .000

Biaya usaha tertinggi: Rp. 2.700 .000

Rata-rata biaya usaha: Rp. 1.857 .821

Sumber: Data diolah, 2020 
Adapun biaya perbulan pedagang nasi goreng yang besarannya $<$ Rp. 1.000 .000 berjumlah 1 pedagang nasi goreng atau $2,56 \%$. Pedagang nasi goreng yang biaya usahanya dikeluarkan terletak antara Rp. 1.001 .000 - Rp. 1.500 .000 berjumlah 16 pedagang nasi goreng atau 41,02\%. Biaya usaha yang terletak antara Rp. 1.501.000 2.000.000 berjumlah 4 pedagang nasi goreng atau 10,26 \% dan Rp. $2.001 .000-$ 2.500.000 serta > Rp. 2.500.000 di Kecamatan Telanaipura, masing-masing berjumlah 4 pedagang nasi goreng atau $10,26 \%$.

\section{Pendapatan usaha}

Pendapatan bersih rata-rata perhari yang diperoleh pedagang nasi goreng di Kecamatan Telanaipura setelah dikurangi biaya diperoleh sebesar Rp. 123.889, sementara untuk penerimaan bersih tertinggi diperoleh pedagang nasi goreng adalah Rp. 259.615 perhari dan terendah adalah Rp. 51.923 perhari. Pendapatan bersih pedagang nasi goreng yang besarnya $<$ Rp. 60.000 berjumlah 4 pedagang nasi goreng atau 11,11\%. Sementara pendapatan bersih perhari yang terletak antara Rp. 61.000 sampai 100.000 berjumlah 9 pedagang nasi goreng atau 23,08 \% dan Rp. 101.000 - Rp. 140.000 berjumlah 14 pedagang nasi goreng atau 35,90\% dan pendapatan bersih ini merupakan paling besar jumlah pedagangnya. Pedagang nasi goreng yang pendapatan bersih perhari terletak antara Rp. 141.000-180.000 berjumlah 7 pedagang nasi goreng atau 17,95\%. Pedagang nasi goreng yang pendapatan bersih perhari terletak antara Rp. 181.000-200.000 berjumlah 3 pedagang nasi goreng atau 7,69\% dan > Rp. 220.0002 pedagang nasi goreng atau $5,13 \%$ dari keseluruhan jumlah pedagang nasi goreng.

Tabel. 15. Pendapatan bersih pedagang nasi goreng ( $\mathrm{Rp} / \mathrm{hari})$

\begin{tabular}{ccc}
\hline Pendapatan bersih & Jumlah & \% \\
\hline$<1.719 .000$ & 7 & 17,95 \\
$1.720 .000-2.819 .000$ & 8 & 20,51 \\
$2.820 .000-3.919 .000$ & 11 & 28,21 \\
$3.920 .000-5.019 .000$ & 11 & 28,21 \\
$>5.019 .000$ & 2 & 5,12 \\
\hline Total & $\mathbf{3 9}$ & $\mathbf{1 0 0 , 0 0}$ \\
\hline
\end{tabular}

Pendapatan Bersih Terendah : Rp. 620.000

Pendapatan Bersih Tertinggi : Rp. 6.700 .000

Rata-Rata Pendapatan Bersih : Rp. 3.156.487

Sumber: Data diolah, 2020

Sementara, bila dilihat dari pendapatan bersih rata-rata perbulan yang diperoleh pedagang nasi goreng di Kecamatan Telanaipura setelah dikurangi biaya diperoleh sebesar Rp. 3.221.103.

Tabel. 16. Pendapatan bersih pedagang nasi goreng (Rp/bulan)

\begin{tabular}{ccc}
\hline Pendapatan Bersih & Jumlah & \% \\
\hline$<1.500 .000$ & 4 & 11,11 \\
$1.501 .000-2.500 .000$ & 7 & 17,95 \\
$2.501 .000-3.500 .000$ & 14 & 35,90 \\
$3.501 .000-4.500 .000$ & 9 & 23,08 \\
$4.501 .000-5.500 .000$ & 3 & 7,69 \\
$>5.500 .000$ & 2 & 5,12 \\
\hline Total & $\mathbf{3 9}$ & $\mathbf{1 0 0 , 0 0}$ \\
\hline
\end{tabular}

Pendapatan Bersih Terendah : Rp. 1.350 .000

Pendapatan Bersih Tertinggi : Rp. 6.750 .000

Rata-Rata Pendapatan Bersih : Rp. 3.221.103

Sumber: Data diolah, 2020 
Sementara untuk penerimaan bersih tertinggi diperoleh pedagang nasi goreng adalah Rp. 6.750 .000 perbulan dan terendah adalah Rp. 1.350 .000 perbulan. Pendapatan bersih pedagang nasi goreng yang besarnya $<$ Rp. 1.500 .000 berjumlah 4 pedagang nasi goreng atau $11,11 \%$. Sementara pendapatan bersih perbulan yang terletak antara Rp. 1.501.000 sampain 2.500.000 berjumlah 7 pedagang nasi goreng atau 17,95 \%. Pendapatan bersih perbulan yang terletak antara Rp. 2.501.000-3.500.000 berjumlah 14 pedagang nasi goreng atau $35,90 \%$ dan pendapatan bersih ini merupakan paling besar jumlah pedagangnya yang ada.

Pedagang nasi goreng yang pendapatan bersih perbulan terletak antara Rp. 3.501.000-4.500.000 berjumlah 9 pedagang nasi goreng atau 23,08\%. Sementara pendapatan bersih perbulan yang terletak antara Rp. 4.501.000-5.500.000 dan > Rp. 5.500.000 masing-masing berjumlah 3 pedagang nasi goreng atau 7,69 dan berjumlah 2 pedagang atau $5,12 \%$ dari keseluruhan jumlah pedagang nasi goreng.

\section{KESIMPULAN DAN SARAN}

\section{Kesimpulan}

Kondisi sosial pedagang nasi goreng di Kecamatan Telanaipura adalah usia ratarata adalah usia produktif yaitu 42,78 tahun. Tingkat pendidikan tertinggi dan paling banyak adalah SMA/SMK. Semua pedagang nasi goreng berjenis kelamin laki-laki. Status perkawinan paling banyak telah kawin. Rata-rata lama berusaha adalah 8,39 tahun. Rata-rata jumlah tanggungan keluarga 4,74 atau 5 orang. Pedagang nasi goreng paling banyak telah memiliki sendiri rumah tempat tinggal. Daerah asal pedagang nasi goreng palin banyak berasal dari Provinsi Jawa Tengah. Rata-rata lama jam kerja pedagang nasi goreng adalah 8,74 atau 9 jam perhari. Rata-rata pedagang nasi goreng memiliki usaha dan tempat usaha sendiri.

Kondisi sosial pedagang nasi goreng di Kecamatan Telanaipura adalah modal usaha pedagang nasi goreng paling banyak adalah milik sendiri. Rata-rata besarnya modal awal usaha adalah Rp. 6.233.333. Rata-rata lama hari berjualan dalam satu bulan adalah 28 hari. Rata-rata harga satu porsi nasi goreng adalah Rp. 13.270,77. Rata-rata jumlah porsi nasi goreng terjual dalam satu bulan adalah 386,46 porsi. Rata-rata biaya usaha perbulan adalah Rp. 53.603.846,15. Rata-rata pendapatan bersih perbulan adalah Rp. 88.120.462.

\section{Saran}

Melihat kondisi sosial pedagang nasi goreng di Kecamatan Telanaipura Kota Jambi, yang cenderung cukup baik, maka melalui dinas/kantor terkait yaitu Disperidagkop Kota Jambi perlu melakukan upaya pembinaan secara rutin mengenai manajemen berusaha yang baik dan benar dan memberikan kredit dengan tingkat bunga pengembalian yang rendah, sehingga pedagang nasi goreng dapat mempertahankan serta mengembangkan usahanya menjadi lebih besar.

Melihat kondisi ekonomi pedagang nasi goreng di Kecamatan Telanaipura Kota Jambi, yang cenderung cukup baik, maka melalui dinas/kantor terkait yaitu Disperidagkop Kota Jambi perlu melakukan upaya pembinaan melalui pemberian pelatihan menjaga makanan yang dihasilkan tetap higenis, memberikan tempat khusus untuk berdagang, memudahkan pemberian izin berjualan, sehinggan mampu mendorong peningkatan ekonomi para pedagang nasi goreng yang ada di Kecamatan Telanipura Kota Jambi. 


\section{DAFTAR PUSTAKA}

Arikunto, Suharsimi. (2010). Prosedur penelitian suatu pendekatan praktik, Rineka Cipta: Jakarta.

Darman. (2015). Kehidupan sosial pedagang kaki lima di Kota Samarinda (Studi Kasus Penjual Jagung Rebus ditepian), Jurnal Sosiologi Konsentrasi, 3(1), 2015: 4159.

Mulyadi, S.(2005). Ekonomi sumber daya manusia; dalam perspektif pembangunan, Raja Grafindo Persada: Jakarta.

MY Hermanzah, R Nurjanah, E Achmad. (2020). Analisis pendapatan pedagang pasar tradisional di Kota Kuala Tungkal Kabupaten Tanjung Jabung Barat (studi kasus pasar ikan parit 2), e-Jurnal Ekonomi Sumberdaya dan Lingkungan, 9 (2), 75-84

P Parmadi, D Hastuti, E Erfit, R Nurjanah, F Zeyava. (2019). Pengolahan limbah organik rumah tangga di Desa Renah Alai Kabupaten Merangin, Jurnal Inovasi, Teknologi dan Dharma Bagi Masyarakat, 1 (1), 43-50

Prawiro, Kusumo.(2001). Ekonomi rakyat: konsep, kebijakan dan strategi, BPFE: Yogyakarta.

Sugiyono.(2012). Metode penelitian pendidikan pendekatan kuantitatif, kualitatif, dan $r \& d$, alfabeta: bandung.

Sujarweni, V. Wiratna. (2015). Statistik Untuk Bisnis dan Ekonomi, Pustaka Baru Press: Yogyakarta.

Wahyuni, Yuyun. (2011). Dasar-dasar statistik deskriptif, Nuha Medika: Yogyakarta. 